\title{
A SURVEY OF CATARACT SURGERY TECHNIQUE IN THE UNITED KINGDOM*
}

\author{
BY \\ E. C. ZORAB \\ Southampton
}

For the purposes of a paper read before the Section of Ophthalmology at the B.M.A. Meeting at Torquay in June, 1960, a questionnaire was sent to a number of surgeons in order to find out the methods currently in use in the United Kingdom.

167 questionnaires were sent out to consultants in all parts of the country and 155 replies were received. Five of these were rejected, because the consultant concerned was not, or was no longer, in surgical practice, so that the results are based on 150 replies. This very gratifying response reflects the great interest taken by nearly everyone in this fascinating operation.

When analysing the results it is important to stress that what was being sought was the usual or normal routine in uncomplicated cases, and it is not always easy to say what is one's usual routine. A certain amount must therefore rest on my interpretation of the replies which were sometimes slightly equivocal in certain respects. The methods used at all stages are analysed in the Tables.

Anaesthesia (Table I, opposite).-Just under 20 per cent. used general and just over 80 per cent. used local anaesthesia.

Exposure (Table I).-Only 25 per cent. now use a speculum as opposed to $66 \mathrm{per}$ cent. using lid sutures to expose the eye. This surely represents a marked trend away from the use of the speculum.

Fixation (Table I). -47 per cent. fix the globe at 3 or 9 o'clock, and 42 per cent. at 6 o'clock. 75 per cent. use a superior rectus suture.

Section (Table II, opposite).-The cataract knife is still the most popular instrument for opening the eye; 80 per cent. use this as against 12 per cent. using keratome and scissors. Two surgeons use a Bard-Parker knife and scissors. 83 per cent. make a conjunctival flap.

Corneo-scleral Wound Sutures (Table II).-There is very little agreement here. 14 per cent. use no suture, 28 per cent. a post-placed one, 28 per cent. a pre-placed one, and 14 per cent. a mixture. Of those using sutures about 80 per cent. use silk and just over 10 per cent. use catgut.

Iridectomy (Table II). -66 per cent. favour a peripheral iridectomy, and 12 per cent. a complete one, 10 per cent. use iridotomy and 2 per cent. leave the iris intact. One surgeon does a preliminary iridectomy.

Zonulolysis (Table II).- It is rather difficult to give an exact percentage here, but as far as I can gather 30 per cent. use it as routine, and a further 20 per cent.

* Received for publication November 18, 1960. 
TABLE I

PREPARATORY STAGES OF CATARACT SURGERY

\begin{tabular}{|c|c|c|}
\hline \multicolumn{2}{|c|}{ Procedure } & \multirow{2}{*}{$\left.\begin{array}{l}\text { Percentage* } \\
20 \\
80\end{array}\right\} 100$} \\
\hline Anaesthesia & $\begin{array}{l}\text { General } \\
\text { Local }\end{array}$ & \\
\hline Exposure & $\begin{array}{l}\text { Speculum } \\
\text { Sutures }\end{array}$ & $25\} 81$ \\
\hline Fixation & $\begin{array}{l}6 \text { o'clock } \\
3 \text { and } 9 \text { o'clock } \\
\text { Superior rectus suture }\end{array}$ & $\left.\begin{array}{l}42 \\
47 \\
75\end{array}\right\} 89$ \\
\hline
\end{tabular}

use it in selected cases. 48 per cent. do not use it at all, and 3 per cent. have given up using it for one reason or another. We will return to this subject later.

Extraction (Table II). - The method of extracting the lens depends on the type of operation employed. 75 per cent. of surgeons prefer intra-capsular and 10 per cent. extra-capsular extraction. The remaining 15 per cent. have no

TABLE II

OPERATIVE PROCEDURE IN CATARACT SURGERY

\begin{tabular}{|c|c|c|}
\hline \multicolumn{2}{|c|}{ Procedure } & \multirow{2}{*}{$\begin{array}{l}\text { Percentage* } \\
\left.\begin{array}{l}80 \\
12 \\
83 \\
13\end{array}\right\} 92\end{array}$} \\
\hline Section & $\begin{array}{l}\text { Cataract knife } \\
\text { Keratome and scissors } \\
\text { Conjunctival flap } \\
\text { No flap }\end{array}$ & \\
\hline $\begin{array}{l}\text { Corneo-scleral } \\
\text { Wound Sutures }\end{array}$ & $\begin{array}{l}\text { Pre-placed } \\
\text { Post-placed } \\
\text { Mixed } \\
\text { Nil }\end{array}$ & $\left.\begin{array}{l}28 \\
28 \\
14 \\
14\end{array}\right\} 84$ \\
\hline Suture Material & $\begin{array}{l}\text { Silk } \\
\text { Catgut }\end{array}$ & $\left.\begin{array}{l}80 \\
10\end{array}\right\} 90$ \\
\hline Iridectomy & $\begin{array}{l}\text { Peripheral } \\
\text { Complete } \\
\text { Iridotomy } \\
\text { Nil }\end{array}$ & $\left.\begin{array}{r}66 \\
12 \\
10 \\
2\end{array}\right\} 90$ \\
\hline Zonulolysis & $\begin{array}{l}\text { Not used } \\
\text { Used as routine } \\
\text { Given up } \\
\text { Used in selected cases }\end{array}$ & $\left.\begin{array}{r}48 \\
30 \\
3 \\
20\end{array}\right\} 101$ \\
\hline Extraction & $\begin{array}{l}\text { Intracapsular } \\
\text { Extra capsular }\end{array}$ & $\left.\begin{array}{l}75 \\
10\end{array}\right\} 85$ \\
\hline $\begin{array}{l}\text { Method for Intracapsular } \\
\text { Extraction }\end{array}$ & $\begin{array}{l}\text { Forceps } \\
\text { Erisophake } \\
\text { Expression }\end{array}$ & $\left.\begin{array}{r}75 \\
13 \\
7\end{array}\right\} 95$ \\
\hline
\end{tabular}

* The failure of the percentages to total 100 is due to the fact that some replies omitted certain questions altogether. 
particular preference. Of the intra-capsular school three-quarters use forceps, 13 per cent. use the erisophake and 7 per cent. use expression only.

Reformation of the Anterior Chamber.-50 per cent. reform the anterior chamber artificially, mostly by air, but a few with saline. In 33 per cent. of all the intracapsular operations, a miotic is instilled into the anterior chamber.

Dressing.-62 per cent. pad both eyes for 24 hours or more after operation and 33 per cent. pad only the operated eye.

\section{Comment}

What conclusions can be drawn from these figures? Several points show up-starting with general anaesthesia. This is certainly increasing, though still used in a minority of cases. I am sure that this increase is due mainly to the excellence of modern anaesthesia, and the virtual disappearance of post-operative vomiting. I am myself much in favour of it and so, I think, are those patients who have had local anaesthesia for one eye and general for the other. The surgeon is absolved from all thought of anaesthesia, the eye is immobile, the muscles relaxed, the tension low, and the danger of retrobulbar haemorrhage absent.

The speculum is fast becoming an obsolete instrument for this operation, and it is being replaced by the safer method of lid sutures.

The superior rectus stitch is not very new, but has proved its worth.

The cataract knife remains the instrument of choice of the majority, and not only among the older generation. Wound suture has proved its worth and silk remains the best material for it.

The methods of intracapsular extraction were not asked for in detail. Forceps remain the commonest instrument used in executing it, though the erisophake is used to quite a large extent. In my opinion the latter method is more certain especially with tense or hard capsules. The striate keratitis which sometimes follows its use is always transient. When using zonulolysis, however, I think that simple expression, perhaps aided by forceps at the upper pole, is often preferable. It is not always easy to insert the erisophake once the lens has been freed from its attachments.

The subject of zonulolysis has been left till last as it is the latest development. There can be no doubt about the value of the enzyme alphachymotrypsin in certain cases, though it is perhaps not quite so innocuous as was at first thought. Many of the earlier reports indicated that there were no side-effects. However, the more recent reports, even those from Barcelona, show that there are certain complications with its use.

My own experience over 2 years has now led me to use it for almost every patient over 10 and under 60 years, and in a few selected cases over this age, and this seems to be a view held fairly widely.

Finally, I should like to thank all those surgeons who responded to this questionnaire, many of them with most encouraging remarks. I would also like to thank Dr. Frank Budden who transferred all the information to punch cards, thus simplifying the analysis. 